\title{
GOUT
}

\section{OBSERVATIONS ON THE EFFECTS OF DRUGS ON PLASMA URIC ACID AND URINARY URIC ACID}

BY

\author{
G. D. KERSLEY, L. MANDEL, and E. BENE \\ From the Royal National Hospital for Rheumatic Diseases, Bath
}

In view of the conflict of opinions on the use of various drugs in gout, the effect of a series of commonly used therapeutic agents on the plasma and urinary uric acid in a series of cases suffering from gout has been investigated. Thirteen patients suffering from classical gout were admitted to hospital and kept under observation. Estimations* of the levels of plasma uric acid (P.U.A.) and urinary excretion of uric acid (U.U.A.) over 24-hour periods were made daily, before, during and after administration of certain drugs which were known, or believed, to influence uric acid levels in the blood and urine. It was hoped that the results might act as a guide for the use of these drugs as therapeutic agents. Those chosen were colchicine, sodium salicylate, glycine, carinamide, cinchophen, and probenecid. Colchicine was chosen because of its undoubted clinical effect, in spite of the absence so far of evidence of its effect on the plasma uric acid level. The literature in connection with glycine has been reviewed by Wrigley (1950). Salicylates were first shown to have an effect on uric acid excretion by Jennings (1937) and cinchophen has been known to have a somewhat similar effect since the work of Nicolaier and Dohrn (1908). The use of carinamide (phenyl methane sulphonanilide), first employed to increase the blood levels of penicillin, was suggested by Professor Heller and Dr. Ginsberg in view of its possible value in reducing the tubular resorbtion of uric acid by the kidneys.

\section{Methods}

In the majority of cases, the drugs were given during those periods in which the patients were free of symptoms (interval gout). In some cases, however, an acute gouty attack or mild gouty pains developed during the time of administration or between courses of two preparations. These clinical changes were noted and an attempt was made to relate them to the drugs concerned and to the uric acid levels. Observations on these are discussed later. All the patients received a normal standard diet. The figures set out in the Table represent the average percentage change in the levels of plasma uric acid and urinary excretion of uric acid over a 3-day period during and after the administration of the preparation concerned, as compared with previous control levels. These percentages are also shown diagrammatically in the Figure (overleaf). The interval between the times of beginning each course was 7 days.

From a series of daily control observations, it was considered that the effect of any drug in lowering the plasma uric acid or in increasing the urinary uric acid was only

* Uric acid was estimated by modification of Benedict's method. 
TABLE

PERCENTAGE CHANGES IN P.U.A. AFTER ADMINISTRATION AND IN U.U.A. DURING ADMINISTRATION OF FIVE DIFFERENT DRUGS

\begin{tabular}{|c|c|c|c|c|c|c|c|c|c|c|}
\hline \multirow{2}{*}{$\begin{array}{l}\text { Case } \\
\text { No. }\end{array}$} & \multicolumn{2}{|c|}{ Colchicine } & \multicolumn{2}{|c|}{$\begin{array}{l}\text { Sodium } \\
\text { Salicylate }\end{array}$} & \multicolumn{2}{|c|}{ Glycine } & \multicolumn{2}{|c|}{ Carinamide } & \multicolumn{2}{|c|}{ Cinchophen } \\
\hline & P.U.A. & U.U.A. & P.U.A. & U.U.A. & P.U.A. & U.U.A. & P.U.A. & U.U.A. & P.U.A. & U.U.A. \\
\hline 1 & +9.6 & $-16 \cdot 2$ & -12 & +130 & $-1 \cdot 5$ & -38 & $-17^{*}$ & $+13^{*}$ & -28 & $-5 \cdot 1$ \\
\hline 2 & $+13 \cdot 6$ & -23 & -65 & +12 & -42 & -36 & - & - & -44 & +66 \\
\hline 3 & $+5 \cdot 5$ & $+32 \cdot 5$ & -70 & -4 & -45 & $+31 \cdot 5$ & - & - & -30 & +56 \\
\hline 4 & $-9 \cdot 6$ & 0 & - & - & - & - & - & - & - & - \\
\hline 5 & +25 & +70 & -20 & +32 & -11 & $-19 \cdot 8$ & $-14 \cdot 5$ & $+6 \cdot 2$ & - & - \\
\hline 6 & $-27 \cdot 5$ & $+12 \cdot 5$ & -67 & +56 & 0 & $+25 \cdot 5$ & $\begin{array}{l}-5 \cdot 6 \\
-39^{*}\end{array}$ & $\begin{array}{l}-2.1 \\
+64^{*}\end{array}$ & $-51 \dagger$ & $+28 \dagger$ \\
\hline 7 & $-22 \cdot 5$ & $-9 \cdot 1$ & -17 & +72 & -16 & +63 & +7 & +46 & $-6 \cdot 8$ & +37 \\
\hline 8 & -26 & -25 & -50 & +46 & $+13 \cdot 6$ & +38 & $-4 \cdot 3$ & $+9 \cdot 3$ & $-26+$ & $\therefore 24+$ \\
\hline 9 & 0 & +20 & -48 & +73 & 0 & $-17 \cdot 6$ & - & - & $-27 \cdot 5$ & +78 \\
\hline 10 & - & - & -56 & +58 & +50 & +36 & $\begin{array}{l}-8 \cdot 8 \\
-18 \cdot 5^{*}\end{array}$ & $\begin{array}{l}+10 \\
+69^{*}\end{array}$ & -50 & -85 \\
\hline 11 & $+6 \cdot 7$ & -13 & -24 & +25 & -19 & $-8 \cdot 8$ & - & - & -24 & -23 \\
\hline 12 & $-9 \cdot 0$ & -24 & -49 & +26 & -17 & -11 & +5.9 & +50 & -28 & - \\
\hline 13 & $-14 \cdot 6$ & $+19 \cdot 5$ & $-19 \cdot 5$ & $\div-77$ & $-17 \cdot 5$ & $+17 \cdot 5$ & - & - & -46 & +100 \\
\hline $\begin{array}{l}\text { Average } \\
\text { per cent. } \\
\text { change }\end{array}$ & 0 & -11 & -41 & +51 & -8 & $\div 16$ & $\begin{array}{l}-2 \\
-25\end{array}$ & $\begin{array}{l}-16 \\
-49^{*}\end{array}$ & -32 & $\div 49$ \\
\hline
\end{tabular}

* Large dose (2 g. 4-hourly).

$7 \frac{1}{2}$ gr. t.d.s. 2 days. 15 gr. t.d.s. 1 day.

significant if there was an average fall of at least 15 per cent. in the level of the plasma uric acid (after administration) and an average rise of at least 30 per cent. in the urinary excretion of uric acid (during administration).

\section{Results}

The following is a summary of the effects of each preparation:

(1) Colchicine.-This was given in tablet form orally in a dose of $1 / 120 \mathrm{gr}$. three times daily for 3 days to twelve patients. In only four cases $(4,6,7,8)$ was there any fall in the level of the P.U.A., the fall varying from 9.6 to $27 \cdot 5$ per cent. (average 21.4 per cent.); in three of these four cases the fall was greater than 15 per cent. In seven cases $(2,3,5,8,9,11,13)$ there was a rise in the U.U.A., the figure varying from 13 to 70 per cent. (average 29 per cent.); in only two of these cases ( 3 and 5) was the rise more than 30 per cent. In only one case (8) was there a concomitant fall in the P.U.A. and rise in the U.U.A., the former being 26 per cent. and the latter 25 per cent. 
Three patients (Cases 2, 4, and 8) developed gouty pains-in one case this amounted to an acute attack of gout-on the day before receiving the course of colchicine. The pains settled down rapidly during colchicine administration.

(2) Sodium Salicylate.-This was given in mixture form in doses of 30 gr. $(2 \mathrm{~g}$.), together with $15 \mathrm{gr}$. $(1.0 \mathrm{~g}$.) sodium bicarbonate four times daily for 3 days to twelve patients. In every case there was a fall in the level of the P.U.A. varying from 12 to 70 per cent. (average $42 \cdot 5$ per cent.); in eleven of the cases the fall was

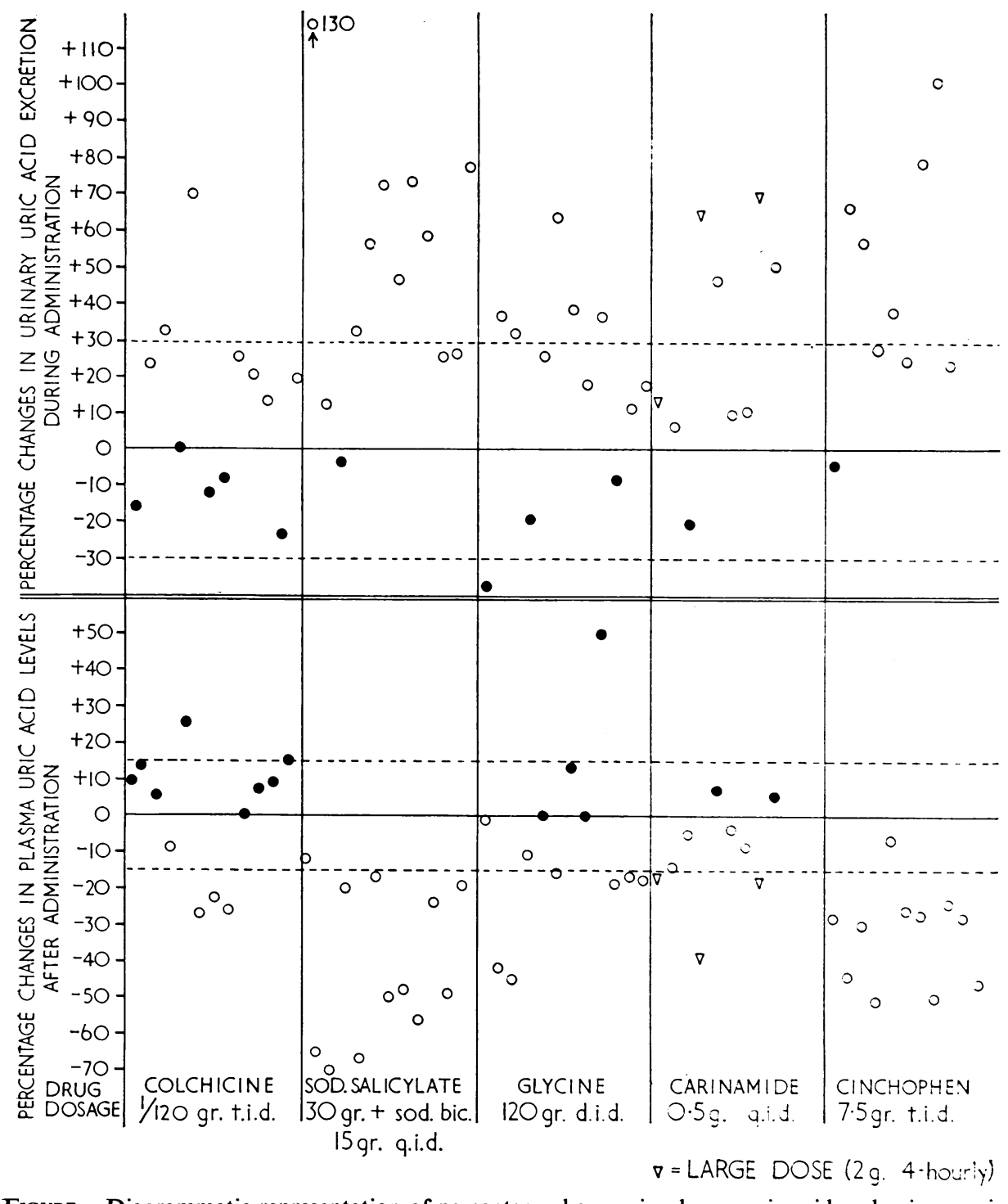

FIGURE.-Diagrammatic representation of percentage changes in plasma uric acid and urinary uric acid after and during administration of five different drugs. 
greater than 15 per cent. In eleven of the twelve cases there was a rise in the U.U.A., the increase varying from 12 to 130 per cent. (average 55 per cent.), and in eight of these the rise was more than 30 per cent. In the one case in which there was a fall in the U.U.A., the fall in the P.U.A. was the maximum noted (70 per cent.).

Four patients $(2,3,8,10)$ developed either an acute attack of gout or milder gouty pains within 72 hours after completing the course of sodium salicylate. This happened in spite of the fact that, at the time that the pains began, the P.U.A. was unusually low, varying from $2.4 \mathrm{mg}$. to $4.4 \mathrm{mg}$. per cent.

(3) Glycine.-This was given orally in doses of 120 gr. $(8 \mathrm{~g}$.) twice daily for 3 days to twelve patients. In eight cases there was a fall in the level of the P.U.A., the figure varying from 1.5 to 45 per cent. (average 21 per cent.); in six of the eight cases the fall was greater than 15 per cent. In nine cases there was a rise of U.U.A., the figure varying from 11 to 63 per cent. (average 30.7 per cent.); in five of the nine cases the rise was more than 30 per cent. Altogether there were only five cases $(2,3,7,12,13)$ in which there was a concomitant fall in the P.U.A. and rise in the U.U.A.

In two patients ( 3 and 5) an attack of gout developed within a day of beginning the course of glycine, and in one patient (11) gouty pains occurred on the day after the course of glycine was completed.

(4) Carinamide.-This drug, phenyl methane (4 $4^{1}$ carboxyl) sulphonanilide, $<=>\mathrm{CH}_{2} \cdot \mathrm{SO}_{2} \cdot \mathrm{NH}<=>\mathrm{COOH}$, was given in cachets or tablets orally. In six patients the dose was $0.5 \mathrm{~g}$. four times daily, and in three $(1,6,10) 2 \mathrm{~g}$. fourhourly for 3 days. Two of these three $(6,10)$ had previously received the smaller dose. In four of the six patients receiving the small dose, there was a fall in the P.U.A. ranging from 4.3 to 14.5 per cent. (average 8.3 per cent.), in five there was a rise in the U.U.A. varying from $6 \cdot 2$ to 50 per cent. (average $24 \cdot 3$ per cent.); in only two of these ( 7 and 12 ) was the rise greater than 30 per cent. In all three patients receiving the larger dose there was a concomitant fall in the P.U.A. and rise in the U.U.A., the former varying from 17 to 39 per cent. (average 28 per cent.), and the latter from 13 to 69 per cent. (average 48.6 per cent.); in all three the fall in the P.U.A. was greater than 15 per cent., and in two of them the rise in the U.U.A. was above 30 per cent.

One patient developed an acute attack of gout within two days of completing the course of carinamide.

(5) Cinchophen.-This was given orally in doses of $7 \frac{1}{2}$ gr. $(0.5 \mathrm{~g}$.) three times daily for 3 days to nine patients, and in doses of $7 \frac{1}{2} \mathrm{gr}$. $(0 \cdot 5 \mathrm{~g}$.) three times daily for two days, and $15 \mathrm{gr}$. $(1.0 \mathrm{~g}$.) three times daily for a third day, to two patients (6 and 8). In all eleven cases there was a fall in the level of the P.U.A. varying from 6.8 to 51 per cent. (average 32.8 per cent.); in ten of them the fall was greater than 15 per cent. In nine of the eleven cases, there was a rise in the U.U.A., varying from 23 to 100 per cent. (average 55 per cent.); in six of these nine the rise was more than 30 per cent. In one case the level of the U.U.A. was not estimated, and in the other it fell by 5.1 per cent.

(6) Probenecid ("Benemid ").-This drug, $p$-(di- $n$-propylsulphamyl)-benzoic 
acid, $\left(\mathrm{C}_{3} \mathrm{H}_{7}\right)_{2} \mathrm{~N} . \mathrm{SO}_{2}<->\mathrm{COOH}$, was given orally in a dose of $0.5 \mathrm{~g}$. four times daily to eight additional patients (not included in Table or Figure). In all cases there was a fall in the level of P.U.A., varying from 18 to 62 per cent. (average 40 per cent.), and a rise in the level of U.U.A., varying from 19 to 120 per cent. (average 55 per cent.). In all cases the fall in P.U.A. was more than 15 per cent., and in five out of the eight, the rise in U.U.A. was more than 30 per cent.

Two patients (one a female suffering from tophaceous gout) developed an acute attack of gout 2 to 3 days after completing the course, when the P.U.A. was comparatively low. In the case of the female, this was the first attack she had had for many years. Two other patients developed an attack of gout on the second day of the three-day course of Benemid; in both cases the P.U.A. was also comparatively low, one being the lowest ever recorded in a total of fourteen estimations, eight of them on consecutive days.

\section{Conclusions}

Observations were made on the effect of a series of drugs on the plasma uric acid and daily excretion of urinary uric acid in thirteen classical cases of gout during the interval phase. Owing to normal variations in uric acid levels, a fall of less than 15 per cent. in the plasma uric acid, and a rise of less than 30 per cent. in the urinary excretion of uric acid was considered of no significance. Taking into account this normal variation, the results were as follows:

(a) Colchicine, 1/120 gr. three times daily-although this drug was clinically effective, in only three out of twelve cases was there a fall in the P.U.A., and in only two out of twelve an increase of the U.U.A.

(b) Sodium Salicylate, 30 gr. $(2 \cdot 0$ g.) four times daily-in eleven out of twelve cases there was a fall in the P.U.A. and in eight an increase in the U.U.A.

(c) Glycine, 120 gr. twice daily-in six out of twelve cases there was a fall in the P.U.A. and in five a rise in the U.U.A.

(d) Carinamide, $0 \cdot 5 \mathrm{~g}$. four-hourly-no patient showed a fall in the P.U.A., but two out of six showed an increase in the U.U.A. On a dosage of $2.0 \mathrm{~g}$. four-hourly, however, three out of three cases showed a fall in the P.U.A. and two out of three a rise in the U.U.A.

(e) Cinchophen, $7.5 \mathrm{gr} .(0.5 \mathrm{~g}$.) three times daily-ten out of eleven showed a fall in the P.U.A., and six out of eleven showed a fall in the U.U.A.

( $f$ ) Probenecid, $0.5 \mathrm{~g}$. four times daily - eight cases all showed a fall in the P.U.A. and a rise in the U.U.A.

The average percentage decreases in plasma uric acid and increases in urinary uric acid were:

\begin{tabular}{lrrr}
\multicolumn{1}{c}{ Drug } & & Decrease $\%$ & Increase $\%$ \\
Colchicine &. & 0 & +11 \\
Sodium Salicylate & -41 & +51 \\
Glycine .. &. & -8 & +16 \\
Carinamide &. & -25 & +49 \\
Cinchophen &. & -32 & +49 \\
Probenecid &. & -40 & +55
\end{tabular}

Although from the clinical point of view we are of the opinion that colchicine is probably the most important single therapeutic weapon in gout, both in the 
acute and interval phase, these figures show that salicylates, cinchophen and, in the larger dosage, carinamide and probenecid are the only drugs which have any significant effect on the plasma and urinary uric acid in the dosage usually employed.

\section{Summary}

The effect of six drugs on the plasma and urinary uric acid in gout has been investigated. Salicylates, cinchophen, large doses of carinamide, and probenecid appeared to produce a significant result, while colchicine and glycine were without this effect.

We should like to thank Dr. Pearson for assistance in the laboratory and the Empire Rheumatism Council for financial help.

\section{REFERENCES}

Adlersberg, D., Grishman, E., and Sobotka, H. (1942). Arch. intern. Med., 70, 101.

Bidmead, D. S. (1951). J. clin. Path., 4. (In the press.)

Jennings, G. H. (1937). “ Reports on Chronic Rheumatic Diseases ”, No. 3, p. $106 . \quad$ Lewis, London.

Nicolaier, A., and Dohrn, M. (1908). Dtsch. Arch. Klin. Med., 93, 331.

Wrigley, F. (1950). Annals of the Rheumatic Diseases, 9, 38.

\section{Goutte: Observations sur les Effets de Divers Médicaments sur l'Acide Urique du Plasma et de l'Urine}

\section{RÉSUMÉ}

On a étudié l'effet de six médicaments sur l'acide urique du plasma et de. l'urine dans la goutte. Les salicylates, la cinchophène, de fortes doses de carinamide, et la probénécide semblaient produire un résultat significatif, tandis que la colchicine et la glycine restaient sans effet.

\section{Gota: Observaciones sobre los Efectos de Varios Medicamentos sobre el Ácido Úrico del Plasma y de la Orina \\ SUMARIO}

Se han investigado los efectos de seis medicamentos sobre el ácido úrico del plasma y de la orina en casos de gota. Salicilatos, " cinchophen ", fuertes dosis de carinamida, y " probenecid" parecían producir un resultado significativo mientras que la colchicina y la glicina fueron carentes de este efecto. 